MATHEWS, Gordon, Linessa Dan LIN, and Yang YANG. 2017. The World in Guangzhou. Africans and Other Foreigners in South China's Global Marketplace. Chicago: Chicago University Press.

Book reviews

Romain Dittgen

\title{
OpenEdition
}

Electronic version

URL: http://journals.openedition.org/chinaperspectives/9265

DOI: $10.4000 /$ chinaperspectives.9265

ISSN: 1996-4617

Publisher

Centre d'étude français sur la Chine contemporaine

Printed version

Date of publication: 8 June 2019

Number of pages: 90-91

ISSN: 2070-3449

\section{Electronic reference}

Romain Dittgen, «MATHEWS, Gordon, Linessa Dan LIN, and Yang YANG. 2017. The World in Guangzhou. Africans and Other Foreigners in South China's Global Marketplace. Chicago: Chicago University Press. », China Perspectives [Online], 2019-2 | 2019, Online since 06 June 2019, connection on 19 December 2020. URL : http://journals.openedition.org/chinaperspectives/9265 ; DOI : https:// doi.org/10.4000/chinaperspectives.9265

This text was automatically generated on 19 December 2020.

(c) All rights reserved 


\section{MATHEWS, Gordon, Linessa Dan LIN, and Yang YANG. 2017. The World in Guangzhou. Africans and Other Foreigners in South China's Global Marketplace. Chicago: Chicago University Press.}

Book reviews

Romain Dittgen

This book provides a fine-grained ethnographic analysis of the role, place, and workings of foreign entrepreneurs involved in trading activities in Guangzhou, one of the world's leading manufacturing powerhouses. It uses the framing of "low-end globalisation" to unpack how the sourcing and shipping of small and large amounts of goods (often copies or knockoffs) to developing countries rely predominantly on factors such as trust, reputation, personalised links, or bribery rather than on formalised contracts and other legal instruments. The underlying complexities, trends, and shifts are narrated primarily through individual stories with sizeable sections of chapters

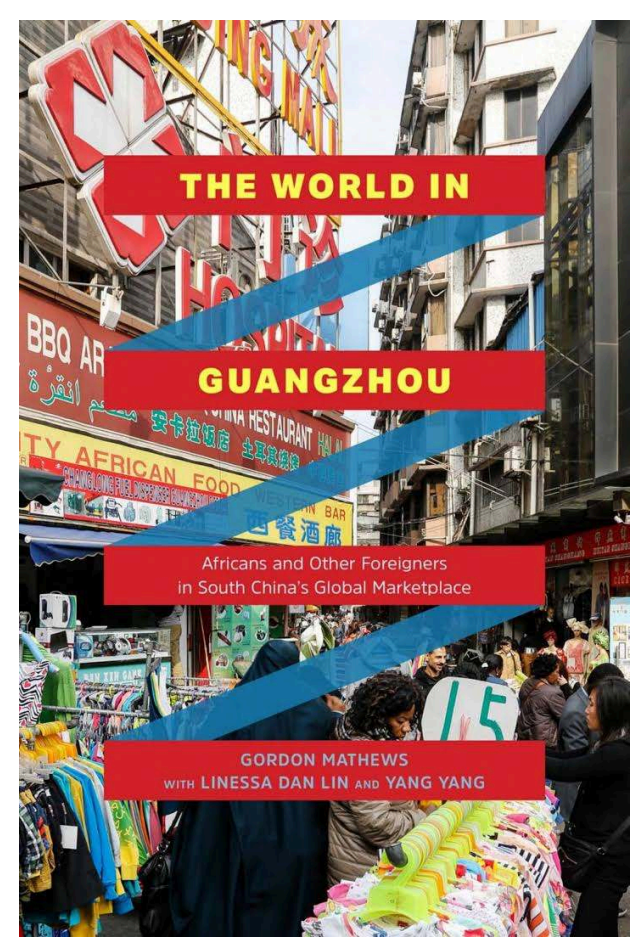


dedicated to direct accounts from foreigners (mainly Africans, but also Arabs and the occasional Westerner) as well as their Chinese counterparts. Through this close-up lens, the authors explore the manoeuvrings of foreigners, especially those from developing countries, in their striving to be successful in business, and to live and sustain their presence in a country that enforces a stringent visa system as a way to limit the settlement of outsiders in Chinese society. The book is penned by Gordon Mathews, but builds on empirical research conducted in close collaboration with Linessa Dan Lin and Yang Yang (acknowledged as co-authors) and with data collected over several years.

2 The book opens by viewing the presence of foreigners from a historical perspective and within a spatial context. If Guangzhou, partly due to its focus on trade, is today one of China's richest and most foreign cities, Mathews cautions against overestimating what, overall, remains a tiny number of foreigners within a metropolis of 13-14 million people. He also points to certain continuities between past and present, such as limited contacts between the host society and outsiders, as well as the geographical concentration of the latter. As part of the introduction, the reader embarks on a virtual walking tour through neighbourhoods that attract a tangible number of foreigners. Descriptions of scenes in tower complexes filled with shops, in various restaurants, bars, hotel lobbies, or religious institutions provide a sense of differentiated spatial dynamics and business strategies. This contrast is largely influenced by origin, religion, class, gender, and legal status. As part of locating the presence of foreigners, a significant portion of the book is set within the confines of two specific neighbourhoods: Xiaobei, hosting people from all over Africa, the Arab world, and the Middle East; and Guangyuanxi, predominantly Nigerian Igbo and Pentecostal Christian. The spatial thread of the book is more complex. Not only does it explore the subtle tactics and temporalities of over-stayers, the narrative also transcends the city limits by following the goods to Eastleigh (a Somali neighbourhood in Nairobi), recounting experiences of traders traveling to Yiwu, Dubai, Bangkok, or Istanbul to source products, and through sharing stories of real or imagined returns to places of origin.

3 Throughout the book, Mathews unpacks a number of predominant categorisations that underpin and characterise the presence of foreigners in Guangzhou. The postulate of a global divide between the developed and developing world is partly explored through questions of race as well as questions of (il)legality, whether of people or goods (Chapter 5). At the same time, by drawing on several portraits of foreigners, the book defies simple interpretations of categories and correlations, asking, for instance, whether discrimination/acceptance and the level and nature of business deals are determined by race, capital, or other factors. Nonetheless, in this context of copresence, where cultural codes are complex, miscommunication and misunderstandings frequently arise. Interactions between Africans and Chinese, Arabs and Africans, Muslims and Christians, amongst citizens from different African countries, as well as domestically between Han and Uighurs, are often guided by stereotypes. This, combined with a highly unequal power balance between Chinese suppliers and African traders, often leads to distinct interpretations of bargaining, accusations of cheating, and challenges in terms of building relations of trust. These difficulties, either systemic (visa regime) or circumstantial (business deal), are countered in different ways. Thus, Mathews discusses the roles of African logistics agents, middlemen, and cultural brokers (Chapter 6) in facilitating business 
connections and the supply of goods to African traders, using different tactics to transport copy and knockoff products, as well as providing practical guidance and advice about Chinese society to newcomers. In a more abstract form, religion and faith also constitute important pillars to foreigners from developing countries in response to adversity and the limited practical power they wield over their everyday lives (Chapter 7).

What about the future of Africans and others foreign entrepreneurs in Guangzhou? The final chapter of the book poses this question while also asking whether China could one day see the emergence of its own "Chinese Barack Obama." Initial business relations have occasionally led to romance, love, and marriage, mostly between African men and Chinese women. Biracial children have been born out of some of these unions. Even so, the author remains rather sceptical about the prospects of a truly multicultural Chinese society in the near future as well as about the long-term viability of these foreigners in the city. Statements by foreign entrepreneurs such as "China gives and China takes away" (p. 134), or "China is a good place to make a living, but not to make a life" (p. 157) point towards a pragmatic yet disillusioned view about their place in the People's Republic of China.

Ultimately, the book provides a layered reading of what it means for a foreigner to live and work in China, especially those from countries that are loosely and often simplistically correlated with poverty and lack of development. By capturing the voices of adventurers, realists, dreamers, misfits, and hustlers while telling stories of success, failure, and making do, Mathews combines broader trends with the complexity of individual trajectories. What is unfortunate is that the framing of the economic activity under examination as low-end globalisation runs the risk of pushing towards the adoption of another duality, the formal versus the informal, as well as of a normative approach towards development. It confines these interactions within a particular timeframe - as lagging behind and having to catch up -, and it does not allow for a multiplicity of trajectories ${ }^{1}$.What this work offers is exactly the kind of material that should make us cautious about romanticising high-end globalisation (given numerous examples of tax fraud/evasion and shady dealings in the so-called formal economy) and to consider the contributions to the real economy made by the entrepreneurs portrayed in the book. ${ }^{2}$ This critique does not take away from the value and importance of the book. Targeted at a broader audience, it is written in an accessible style with academic argumentation mostly confined to endnotes, allowing it to be read at different levels. Furthermore, Mathews' tendency towards including anecdotes, at times provocative and humorous, makes The World in Guangzhou an enjoyable read, of interest to anyone eager to know more about the human side of globalisation processes.

\section{NOTES}

1. Massey D. 2005. For Space. London: Sage Publications. 
2. A quote in the book about Eastleigh, described as "Wall Street on steroids" (p. 109), indirectly exemplifies the need to think beyond economic binaries and categorisations.

\section{AUTHOR}

ROMAIN DITTGEN

Romain Dittgen is a Post-doctoral Fellow at the African Centre for Migration \& Society and the South African Research Chair in Spatial Analysis \& City Planning, University of the Witwaterstrand.romain.dittgen@wits.ac.za 